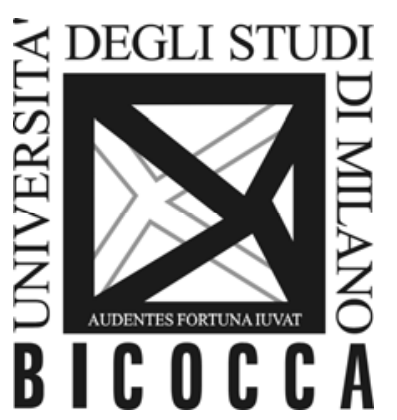

\author{
DEPARTMENT OF ECONOMICS, \\ MANAGEMENT AND STATISTICS \\ UNIVERSITY OF MILAN - BICOCCA
}

DEMS WORKING PAPER SERIES

\title{
Education and Migration: Empirical Evidence from Ecuador
}

Chiara Falco

No. 297 - March 2015

Dipartimento di Economia, Metodi Quantitativi e Strategie di Impresa Università degli Studi di Milano - Bicocca

http://dems.unimib.it/ 


\title{
Education and migration: empirical evidence from Ecuador*
}

\author{
Chiara Falco ${ }^{\dagger}$
}

\begin{abstract}
This study examines how the educational level attained by individuals affects their migration propensity. Using an original 2006 Ecuadorian survey, which gathered information on household members who were not in the country at the time of the survey (i.e., emigrants), we implement a Regression Discontinuity Design and control for potential endogeneity of the education explanatory variable based on the 1977 educational reform in Ecuador. Our results provide evidence of positive self-selection among migrants. Taking into account the $27-57$ age sample, an individual with a lower secondary level of education increases the migration propensity by $31.30 \%$; this propensity is even higher $(34.47 \%)$ when the sample of migrants is restricted to the urban areas. Considering both country-specific characteristics and gender differentials, our results do not indicate a significant impact of an increase in human capital on the male migration propensity. However, there is a positive and significant effect on the female migration propensity, in particular, for women from larger cities. The results are consistent with theoretical models related to positive self-selection in response to labor market distortions, such as the disparities between genders.
\end{abstract}

Keywords: International Migration, Education, Gender

JEL classification codes: F22, J16, O15, I25

\footnotetext{
*The author wish to thank Mariapia Mendola and participants to the CIdE Workshop in Econometrics and Empirical Economics in Perugia for useful comments and inputs. Usual disclaimers apply.

${ }^{\dagger}$ Department of Economics. University of Milano Bicocca - UCSC. E-mail: c.falco@campus.unimib.it
} 


\section{Introduction}

International migration is a phenomenon that has been studied for a long time. In 2013, migrants numbered more than 230 million, representing $3.2 \%$ of the world population ${ }^{1}$. According to the United Nations statistics, with specific reference to worldwide data, the percentages of female migrants rose from 1960 (46.7\%) to $2013(48.0 \%)$ and, at present, women comprise the majority of international migrants. The increasing participation of women in the process of migration supports specific economic issues related to the gender dimension of the determinants and consequences of migration (Beine and Salomone (2013), Docquier et al. (2012)). In this instance, education can be considered an important variable in deterring and influencing migration behavior, and it could also help in explaining gender differences.

Despite the fact that the literature on the brain drain ${ }^{2}$ has significantly evolved, little is known about the role of education in determining the migration propensity by gender. Part of the research is focused on the self-selection of male migrants; however, a smaller part of the research is devoted to women. Our contribution aims to fill this gap through an analysis of the determinant effects in the migration process, such as education and gender at the micro level. The literature on the brain drain and self-selection has produced conflicting results in terms of the migrants' educational skills. Migrants are positively selected based on several characteristics, including education (Chiquiar and Hanson (2005), Feliciano (2005), McKenzie and Rapoport (2010)), and this positive self-selection is due to the fact that highly skilled individuals are more efficient in the migration process because of their higher utility regarding migration costs (Chiswick, 2000), which are decreasing with respect to an increase in educational levels (Chiquiar and Hanson, 2005). However, as noted by Feliciano (2008), 'less is known about the differing roles of education regarding male and female migrants'.

Recently, two new macro level datasets containing information on the gender structure of high-skilled emigration in OECD countries (Dumont et al. (2007), Docquier et al. (2008)) have confirmed the increasing participation of women in international migration and indicated that skilled women represent higher emigration rates than skilled men, suggesting that skilled women evidently have a

\footnotetext{
${ }^{1}$ International Migration report from 2013 by the United Nations Statistics Division (UNSD), Department of Economics and Social Affairs, Population Division.

${ }^{2}$ The definition of the term 'brain drain' can be attributed to Beine et al. (2010). It describes the international allocation of human capital resources in the case of relatively highly educated migrants that is mostly applied in the context of the South-North migration path.
} 
higher propensity to emigrate. Following this approach, the evidence indicates that the female migration rate for the non-OECD countries (88\% of the total number of countries) is higher than that for males and this tendency is most pronounced for the highly skilled individuals. In particular, the migration rates of females with post-secondary education are, on average, $17 \%$ higher than those of males ${ }^{3}$.

This study utilizes the Ecuadorian Encuesta Nacional sobre el Empleo y Desempleo en el Area Urbana y Rural, (ENEMDU henceforth) survey at the micro level. Collected in December 2006, the survey provides data on resident and migrant members of the sampled households. The originality of this dataset is based on information regarding individuals residing abroad for at least six months at the time of the survey, both for the rural and urban areas. The main concern is the potential bias that could arise when considering education - our explanatory variable - as exogenous. The decision to emigrate, in fact, may depend on factors that are unobservable. To address this issue, we implement a Regression Discontinuity Design (RDD) and take advantage of the 1977 educational reform in Ecuador that increased the years of compulsory schooling from six to nine years. In more detail, Law n. 1903 of RO 461 November 11, 1977 ${ }^{4}$ came into effect on January 12, 1978 and increased the years of compulsory schooling from six years (primary education only) to nine years (six years of primary education and three years of lower secondary education). Further, individuals potentially affected by the reform were less than 14 years old in 1978. Indeed, those born in 1964 were required to stay only an additional year in school, while those born in 1965 (1966) had to stay in school for two (three) more years, and so on. Due to the reform, individuals were assigned additional schooling that depended on their date of birth (i.e., randomly with respect to their migration propensity). This enforcement supported the exogeneity of such schooling reform (Acemoglu and Angrist (1999), Acemoglu and Angrist (1991)). Empirically, we find a positive self-selection so that the increase in the level of education can be treated as a 'migration push factor'. What is happening in Ecuador is a brain-drain effect, where the increase in the years of compulsory schooling seems to push

\footnotetext{
${ }^{3}$ Researchers have reported that a higher female educational attainment is related to lower fertility rates and improved health, where infant mortality rates tend to be lower and their children's educational attainment tends to be higher (Behrman and Deolalikar, 1987). Other studies have emphasized the role of female education in raising labor productivity and economic growth, suggesting that educational gender gaps are an impediment to economic development (World Bank, 2001).

${ }^{4}$ This 1977 Law was substituted by Law n.127 on April 15, 1983, but without any change in the years of compulsory school attendance.
} 
its citizens toward the Northern countries, where socio-economic conditions are certainly better than in the country of origin. Moreover, analyzing the results by gender, highly skilled women are positively related to the migration propensity. Therefore, the education push factor is more influential to those who suffer from labor market distortions.

The remainder of the paper is organized as follows. Section 2 presents a literature review that focuses on the relationship between migration and education, followed by the specific characteristics of migration in Ecuador. Section 3 outlines the data, descriptive statistics, and the identification strategy. Section 4 reports the first-stage, baseline, and RDD results, and Section 5 discusses the findings and concludes.

\section{Literature Review}

\subsection{Relationship between Migration and Education}

The literature on which we focus is related to the determinants of migration, in particular, to the role of education. Self-selection (i.e., how migrants are selected with respect to their educational level) and the brain drain (i.e., the international allocation of highly skilled migrants) are both widely explored topics in the context of development economics and are usually connected with wage differentials between the origin and destination countries. In this instance, education can be considered as one of the main determinant of wages ${ }^{5}$. However, the reasons to migrate can also be related to labor market distortions, which are identified as discrimination and gender differences at the individual level. Our study aims to find the main driver in the migration process decision whenever a selection based on education emerges.

Starting from the human capital model of investment in migration (Sjaastad, 1962), educational self-selection presents various patterns depending on the mi-

\footnotetext{
${ }^{5}$ See Dustmann and Glitz (2011) for a review of the literature on education and migration when individuals make simultaneous decisions on their level of education and whether to migrate. The level of education attained at home depends on the possibility to migrate in the future (Mountford (1997), Stark et al. (1997), Beine et al. (2001)). The majority of the literature on migrant self-selection and the brain drain with respect to educational attainment analyze the pattern between Mexico and the United States (Chiquiar and Hanson (2005), McKenzie and Rapoport (2010), Ibarraran and Lubotsky (2007), Moraga (2011)).
} 
grant's skill profile (wage) both at his/her origin and destination, and whether the migration costs increase or decrease in accordance with individual skill level. In the theoretical model proposed by Sjaastad (1962), self-selection is mainly driven by wage differentials net of migration costs, and investments in human capital are probably as important or even more important than the migration process itself. The age variable influenced Sjaastad's results on earning differentials among occupations and locations. Following Sjaastad (1962), McKenzie and Rapoport (2010) proposed a new theoretical framework by which network effects were the main causes in shaping the self-selection pattern in the Mexico-US migration. They argued that networks act to lower migration costs by providing information that relaxes credit constraints. As a consequence, networks play a pivotal role in determining the pattern of migration; in particular, they prove that there is evidence of negative self-selection in communities with stronger networks. These results also confirm Chiswick's (1999) model, where migration costs are lower for highly than for poorly skilled individuals; the pattern of self-selection should depend on the cost of the migration process for each individual in a given community and, by definition, networks lower the migration costs. Chiquiar and Hanson (2005) present a model where migration costs are assumed to decrease according to the level of schooling, even if the relative returns to skill levels are lower at the point of destination. Following Borjas (1991) theoretical model, they indicate that migrant selection in a country such as Mexico may be negative, intermediate, or positive, depending on the expense of the migration and how this cost varies by skill. They argue that as the return to schooling is higher in Mexico, individuals with higher levels of education are less likely to migrate. Generally, Mexican migrants are less educated than Americans but more educated than other Mexicans. One of the limits of their findings is the fact that intermediate or positive selections are only given in terms of observable characteristics, even if there is some evidence of the role of unobservable characteristics in the migration decision. Opposite results, however, are found in Ibarraran and Lubotsky (2007). Using the 2000 census data, they found that lower-skilled Mexicans are more likely to migrate than higher-skilled Mexicans, thus supporting the negative self-selection of migrants. This is consistent with the fact that the possibility to obtain greater returns to skill levels in Mexico is an incentive for the better-skilled Mexicans to remain in Mexico and for the less-skilled Mexicans to migrate to the United States. Borjas (1987) argued that individuals also migrate from countries with high earnings inequality to countries with low earnings inequality, underlining the negative self-selection in countries (whether there is a high return based on 
skill level or wage dispersion), as in the United States. A pattern of negative selection based on education emerges if the migrants' relative return is lower at their destination than in their country of origin. Using data on emigrant stocks by educational level and country of origin for OECD destinations, Grogger and Hanson (2011) found that a linear income maximization model could explain the relative return to education as a driver of migrant self-selection.

Focusing on the gender dimension, there is limited evidence to suggest that women are more positively selected than men when it comes to education. Kanaiaupuni (2000) shows that higher level of education raises the odds of female migration, but lowers the odds of male migration. Similarly, Feliciano (2008) indicates that female migrants from Mexico for the 1960-2000 period were more highly selected than male migrants. Using the Docquier et al. (2009) dataset, Docquier et al. (2012) find that conventional push factors affect women and men in different ways. As an example, there is a positive (negative) relation between female (male) emigration and the average human capital level in the origin country. Additionally, the distance from the origin country to the OECD country has a positive association with highly skilled female emigration but a negative association with men. Moreover, all of these aspects may be related to gender discrimination (Docquier et al., 2012) .

Following this argument, there is a possibility that women have an increasing propensity to migrate because they may have difficulties finding an adequate job in their original country, even with a college degree. In this case, discrimination would result in a positive selection for women ${ }^{6}$. Recent literature, such as Bang and Mitra (2011) and Baudassé and Bazillier (2011), tried to aggregate various variables into indices of gender inequality and female economic opportunities related to the propensity for women to migrate. They found that fertility rates and gender gaps in schooling are negatively related to female migration. In particular, a decrease in gender inequality is associated with higher female migration rates, especially for the highly skilled. Ferrant and Tuccio (2015) employ measures of discriminatory institutions from the OECD Development Centre. They show that variations in their measures of discriminatory institutions are significantly related

\footnotetext{
${ }^{6}$ As an exercise, following the idea of Borjas (1987) and the argument of Docquier et al. (2012) we can look at the Gender Discrimination Index (GDI), which is a Human Development Index that controls for gender. If women suffer relatively high levels of discrimination in one country (such as Ecuador) and experience relatively lower levels of discrimination in another country (such as the United States, Spain, or Italy), there are reasons to argue that women with a higher education will seek to migrate to places with better opportunities. In our case, GDI is equal to 0.44 in Ecuador, 0.25 in the United States, 0.10 in Spain, and 0.09 in Italy. Therefore, we can support this theoretical idea.
} 
to female migration but not to male migration. However, they do not focus on highly skilled individuals who migrate.

\subsection{Migration in Ecuador: Empirical Evidence}

There are few studies on the link between migration and education in Ecuador. However, the relevance in studying the Ecuadorian framework can be related to two main reasons. Ecuador has experienced an exodus of migrants that was

driven by several economic crises since the late 1990s. Moreover, since 2000, more than 600,000 Ecuadorians have left the country to migrate to primary destinations that include the United States, Spain, and Italy (Larrea (2004), Jokisch and Pribilsky (2002), Soruco et al. (1951), Bertoli et al. (2011), Bertoli et al. (2013)). In Bertoli (2010), the variety in the size of established migration networks across destinations, including their geographical variability within Ecuador, provides an important analytical opportunity to assess the role of past migrations in shaping current migration decisions. He supports the theoretical prediction that the increasing size of networks increases the likelihood or the extent of the migrants' negative self-selection with respect to education. He sorted Ecuadorian migrants across multiple destinations, which provided the opportunity to dismiss the concern that migration networks might correlate with unobserved county-specific factors that induce the migrants' negative self-selection based on education. Bertoli and Marchetta (2014) found evidence of a significant impact of migration on poverty among migrant households that was lower than if they had focused on the recipient households.

Until now, the majority of the literature has proposed analyses about whether education affects the migration propensity through other factors or channels (i.e., expected wage, migration costs, labor market distortions, etc.) or as an exogenous variable. Here, the originality of our study is the fact that we consider education to be endogenous, and we solve the problem of possible bias in the results through the use of instrumental variable estimations. 


\section{Data and Methods}

\subsection{Dataset and Descriptive Statistics}

The empirical analysis is based on ENEMDU, a labor market survey collected by the Instituto Nacional de Estadistica y Censos (INEC). Starting in 2005, the INEC adopted a particular definition of household membership that included household members who reside outside the country. Hence, they consider that an emigrant is an individual who resides continuously for more than six months in another country. The peculiarity of this survey is that the demographic information on current migrants is provided by another household member who is still in Ecuador at the time of the survey. For our empirical analysis, we consider the December 2006 survey, which comprises both the urban and rural areas, and is designed to ensure that all 21 Ecuadorian provinces are represented. The estimation sample includes individuals from a particular age sample (27-57 years) that is minus and plus 15 years from the 1964 specific cutoff point ${ }^{7}$.

After accounting for any missing values, we end up with a sample of 11,512 households. Overall, the migrants represent $4.57 \%$ on the total population; in particular, men are $5.67 \%$, whereas women are $3.54 \%$. Table 1 reports the individual characteristics by gender and migration status, showing differences in the descriptive statistics between non-migrants and migrants. In general, international migrants are, on average, younger and better educated, so they tend to stay in school until their 10th year; i.e., until they are almost 15 years. They have larger families than non-migrants and mostly come from urban areas (62\%). These preliminary descriptive statistics are consistent with other empirical studies (Bertoli et al. (2011), Bertoli et al. (2013), Moraga (2011)).

In general, both men and women migrants stay at school longer than nonmigrants. Men are inclined to finish compulsory school; however, they do not attend additional years of schooling ${ }^{8}$. In contrast, women, on average, stay in school for almost 11 years. Considering differences in marital status, a higher percentage of male and female non-migrants are married and the percentage level decreases substantially in the case of migrant women (54\% versus $71 \%$ for nonmigrant women). If we consider the household composition, there are no significant differences between migrants and non-migrants. Splitting the number of

\footnotetext{
${ }^{7}$ Justification of this age sample will be provided in the identification strategy paragraph.

${ }^{8}$ To control for the variability of educational levels among migrants, and taking into account the destination countries, migrants to the United States have 10.1 years of education, while migrants to Spain and the rest of the world have 11.2 and 12.8 years of schooling, respectively (Bertoli, 2010).
} 
Table 1: Descriptive statistics

\begin{tabular}{|c|c|c|c|c|}
\hline & \multicolumn{2}{|c|}{ Non Migrants } & \multicolumn{2}{|c|}{ Migrants } \\
\hline & Mean & Std. Dev. & Mean & Std. Dev. \\
\hline & \multicolumn{2}{|c|}{ Panel A: Total (N. obs 25893) } & \multicolumn{2}{|c|}{ Panel A: Total (N. obs 1239) } \\
\hline Years of School. & 8.34 & 5.09 & 10.02 & 4.34 \\
\hline Female & 0.52 & 0.50 & 0.40 & 0.49 \\
\hline Married & 0.73 & 0.44 & 0.57 & 0.49 \\
\hline Divorced & 0.08 & 0.27 & 0.06 & 0.24 \\
\hline Family size & 5.13 & 2.38 & 6.02 & 2.51 \\
\hline Elderly & 1.20 & 0.49 & 1.51 & 0.74 \\
\hline Children 0-5 & 0.56 & 0.84 & 0.32 & 0.64 \\
\hline Children 6-12 & 0.88 & 1.01 & 0.67 & 0.95 \\
\hline Children 13-15 & 0.39 & 0.60 & 0.34 & 0.58 \\
\hline Employed & 0.78 & 0.41 & 0.77 & 0.42 \\
\hline \multirow[t]{2}{*}{ Urban Area } & 0.57 & 0.49 & 0.62 & 0.48 \\
\hline & \multicolumn{2}{|c|}{ Panel B: Men (N. obs 12306) } & \multicolumn{2}{|c|}{ Panel B: Men (N. obs 740) } \\
\hline Years of School. & 8.48 & 5.00 & 9.42 & 4.20 \\
\hline Married & 0.76 & 0.43 & 0.60 & 0.49 \\
\hline Divorced & 0.06 & 0.24 & 0.04 & 0.20 \\
\hline Family size & 5.08 & 2.38 & 5.99 & 2.41 \\
\hline Elderly & 1.19 & 0.50 & 1.47 & 0.71 \\
\hline Children 0-5 & 0.57 & 0.84 & 0.33 & 0.63 \\
\hline Children 6-12 & 0.85 & 1.00 & 0.68 & 0.93 \\
\hline Children 13-15 & 0.36 & 0.59 & 0.35 & 0.58 \\
\hline Employed & 0.96 & 0.20 & 0.87 & 0.34 \\
\hline \multirow[t]{2}{*}{ Urban Area } & 0.56 & 0.50 & 0.59 & 0.49 \\
\hline & \multicolumn{2}{|c|}{ Panel C: Women (N. obs 13587) } & \multicolumn{2}{|c|}{ Panel C: Women (N. obs 499) } \\
\hline Years of School. & 8.21 & 5.17 & 10.93 & 4.42 \\
\hline Married & 0.71 & 0.45 & 0.54 & 0.50 \\
\hline Divorced & 0.10 & 0.30 & 0.09 & 0.28 \\
\hline Family size & 5.17 & 2.38 & 6.08 & 2.65 \\
\hline Elderly & 1.21 & 0.49 & 1.58 & 0.78 \\
\hline Children 0-5 & 0.56 & 0.84 & 0.30 & 0.66 \\
\hline Children 6-12 & 0.90 & 1.03 & 0.65 & 0.98 \\
\hline Children 13-15 & 0.41 & 0.61 & 0.32 & 0.57 \\
\hline Employed & 0.63 & 0.48 & 0.62 & 0.49 \\
\hline Urban Area & 0.58 & 0.49 & 0.68 & 0.47 \\
\hline
\end{tabular}

Source: authors' elaborations on ENEMDU 2006. 
children within the household with respect to their age (0-5 years, 6-12 years, and 13-15 years), the numbers are similar, with the exception of migrant women who have fewer children within the household than non-migrant women. The coefficients are significant and similar to those for men. Differences emerge, even when considering family size: on average, one more member resides in a migrant household. This could be consistent with the fact that in the absence of one adult member due to migration, children or other family members from the original household join their extended family, which includes parents, grandparents, uncles, cousins, etc. Figure 1 reports the educational levels attained before migration, differentiated between no education and by primary, secondary, and university educational levels.

Figure 1: Level of education before migration (\% values)

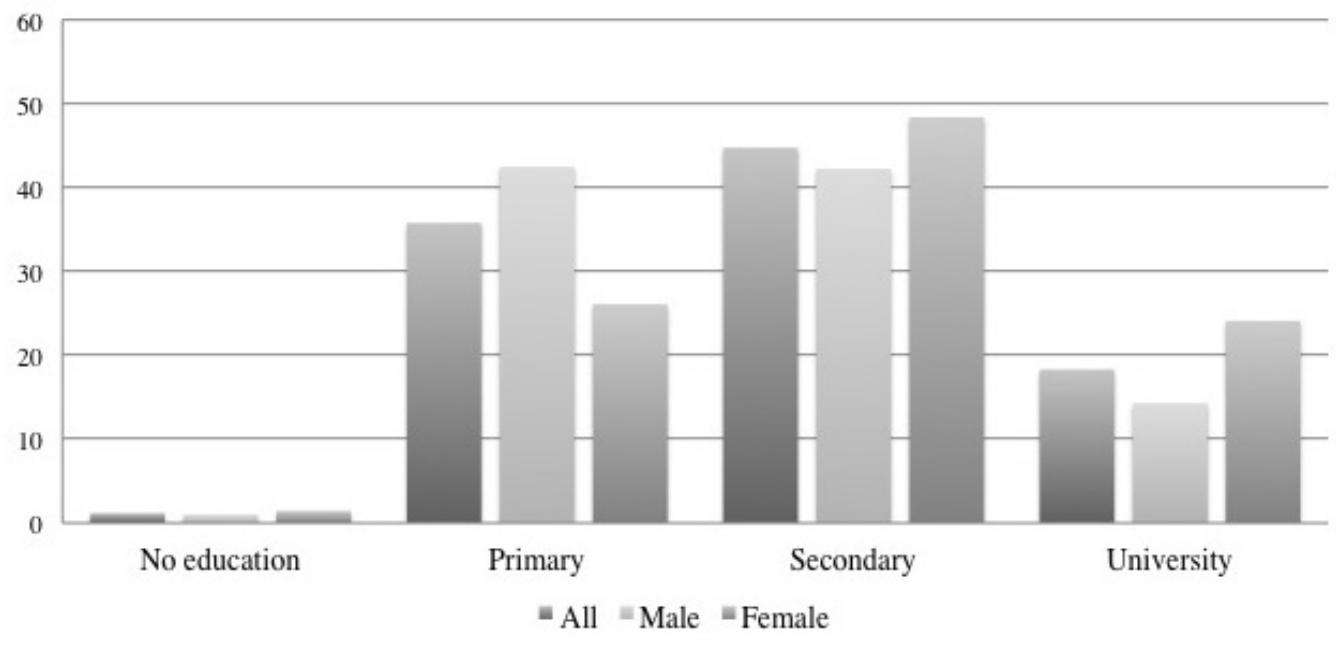

Source: authors' elaborations on ENEMDU 2006.

The percentage of non-educated migrants is similar for men and women, whereas the differences are more evident in terms of primary, secondary, and university educational levels. Almost $40 \%$ of men have primary and secondary educational levels; however, the percentage decreases to $15 \%$ for the university level. Women have more secondary (48\%) and university (22\%) level education than men, and are therefore less represented than men in terms of primary education (24\%). Considering international migrants, we find evidence that women are positively self-selected with respect to their upper educational levels. This is consistent with the fact that migrant women appear to remain at school for more years than men, presumably because, as noted by Docquier et al. (2012), the labor market is not able to absorb them, in particular, when they have attained 
a higher education.

Table 2 presents the difference in education by gender between those who were exposed to the 1977 educational reform and those who were not. We divide the sample into two groups: individuals aged 27-42 years and individuals aged 43-57 years. Migrant women are, on average, more educated than men, in particular, after the implementation of the reform.

Table 2: Non migrants and migrants treated or not by the educational reform (\% values)

\begin{tabular}{|c|c|c|c|c|c|c|}
\hline & \multicolumn{3}{|c|}{ Treated } & \multicolumn{3}{|c|}{ Non treated } \\
\hline & Total & Men & Women & Total & Men & Women \\
\hline \multicolumn{7}{|c|}{ Panel A: Non Migrants } \\
\hline No education & 3.34 & 2.81 & 3.83 & 12.96 & 9.41 & 16.32 \\
\hline Primary & 39.52 & 40.64 & 38.48 & 54.14 & 56.08 & 52.30 \\
\hline Secondary & 37.80 & 38.60 & 37.06 & 19.54 & 19.62 & 19.47 \\
\hline University & 19.34 & 17.95 & 20.63 & 13.36 & 14.90 & 11.91 \\
\hline \multicolumn{7}{|c|}{ Panel B: Migrants } \\
\hline No education & 0.70 & 0.84 & 0.50 & 2.92 & 1.76 & 4.81 \\
\hline Primary & 32.47 & 39.14 & 23.26 & 43.80 & 48.24 & 36.54 \\
\hline Secondary & 49.27 & 46.94 & 52.49 & 37.59 & 31.76 & 47.12 \\
\hline University & 17.56 & 13.09 & 23.75 & 15.69 & 18.24 & 11.54 \\
\hline
\end{tabular}

Source: authors' elaborations on ENEMDU 2006.

As Table 2 shows, the effectiveness of compulsory education is evident. In fact, considering the whole sample, the difference between years of schooling among treated and non-treated individuals is 3.45 years more for men and 4.27 years more for women ${ }^{9}$. Figure 2 presents the employment status before migration by gender.

On the one hand, men are more employed than women. On the other hand, in line with the educational distribution among migrants, women are more represented in terms of individuals who are both working and studying, or only studying. Furthermore, we computed a measure of household assets by aggregating seven variables that provide information on the ownership of goods and characteristics of the household through principal component analysis (PCA) to convert a set of correlated variables into a set of uncorrelated variables called the Principal Component ${ }^{10}$.

\footnotetext{
${ }^{9}$ To find these coefficients, we computed an OLS regression of the explanatory variable (reform) on years of schooling for each individual who had completed their education at the time of the survey. All coefficients are statistically significant at $1 \%$.

${ }^{10}$ The variables are: the number of rooms in the house, including bathrooms; dummies signaling whether the household owns a motorbike, bicycle, or car; the number of personal computers that are in the house (Bertoli, 2010).
} 
Figure 2: Employment status before migration (\% values)

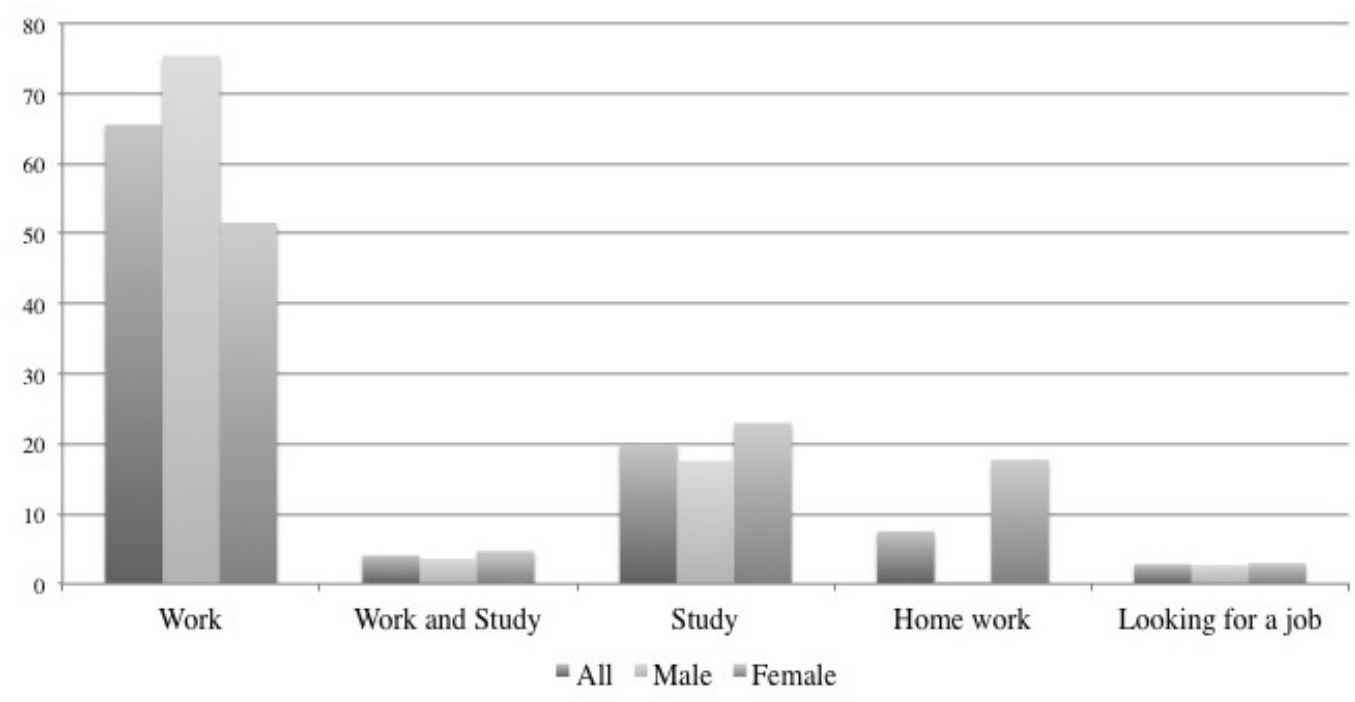

Source: authors' elaborations on ENEMDU 2006.

\subsection{Identification Strategy}

As proposed by the literature, migration can be viewed as a selective process in which migration behavior is driven by individual and household characteristics that cannot be observed. We address the potential endogeneity bias by using the Instrumental Variable (IV) strategy. We consider the 1977 reform as the IV and follow a RDD approach (Thistlethwaite and Campbell, 1960). Due to the reform, individuals were assigned additional schooling depending on their date of birth; i.e., randomly with respect to their migration propensity. This supports the exogeneity of a schooling reform (Acemoglu and Angrist (1999), Acemoglu and Angrist (1991)).

The importance of the RDD strategy is that it can be related to all non-experimental settings, where individuals are assigned to a treatment group depending on the value taken by a specific variable (Lee and Lemieux, 2010). The RDD requires that a particular threshold for an observed characteristic defines the treated and non-treated groups. Furthermore, it assumes that individuals close to the cut-off point are identical in all of the characteristics, except for the assignment variable. In this case, the design is fuzzy, since compliance with the reform was not perfect and the reform was implemented gradually and with some difficulties. As proposed by the theoretical literature, the compliers are those individuals who, in the absence of the reform, would have dropped out of school at the age of 11 , which was the minimum legal age. 
To implement the RDD, we proceed as follows: first, we verify the presence of the discontinuity; second, we determine its size over the distribution. Following Fort et al. (2011), each conditional expectation is smoothed-out by means of a parsimonious global polynomial representing the year of birth (Y) and the instrument $\left(\operatorname{Re} f_{g}\right)$, which takes the value 1 if the individual was born after the threshold date of birth and the value 0 otherwise. The smoothed values are used to construct the counterfactual values at the various threshold levels (see Figure 3 in the Appendix). Figures (3.a) and (3.b) report graphical representations that consider the whole population. Figures (3.d) and (3.f) show the ratio of women and men completing their lower secondary schooling by birth cohort. A discontinuity for the 1964 cohort is evident for both women and men. Figures (3.c) and (3.e) report the same information with years of schooling as our explanatory variable. The graphical representation presents a higher discontinuity for the 1964 cohort; i.e., significant and positive results for the whole population and for women. Moreover, the discontinuity is even higher if we consider 'years of schooling' as the dependent variable.

Our 'fuzzy' RDD strategy can be described as follows:

$$
\begin{aligned}
& M_{g}=\alpha_{0}+\sigma_{1}+\delta_{1}+\mu E d u_{g}+\alpha_{1} f(Y-C)_{g}+\alpha_{2} s(Y-C)_{g} * R e f_{g}+\alpha_{3} X_{g}+\varepsilon_{g} \\
& E d u_{g}=\beta_{0}+\sigma_{1}+\delta_{1}+\gamma R e f_{g}+\beta_{1} f(Y-C)_{g}+\beta_{2} s(Y-C)_{g} * R e f_{g}+\beta_{3} X_{g}+u_{g}
\end{aligned}
$$

Equation (1) is for the outcome variable; i.e., $M_{g}$ is defined as a dummy variable, which is equal to 1 if an individual is a migrant and is equal to 0 otherwise, where $g$ stands for gender ( $g=1$ for all samples, $g=2$ for men, and $g=3$ for women). Following Braga and Bratti (2013), we control for two polynomials in the birth cohort; $f(:)$ and $s(:)$. The treatment is determined by age, so that the dummy variable $f(Y-C)_{g}$ is equal to 1 if the individual is younger than the cut-off age and is equal to 0 otherwise. $Y$ is the year of birth and $C$ is the cut-off year (1964). Edu is the endogenous explanatory variable. To complete the analysis, we consider two explanatory variables as measures of the educational level:

1. a lower secondary school level that is a dummy equal to 1,0 otherwise; and

2. years of schooling completed by each individual, where $\operatorname{Re} f_{g}=I(Y \geq C)$ is a dummy for the reform eligibility (i.e., $\mathrm{Y} \geq C$ ).

$\mathrm{X}_{g}$ is a vector of covariates, which includes demographic and household characteristics. $\sigma_{1}$ and $\delta_{1}$ are country and regional fixed effects, which control for all 
unobserved cross-country heterogeneity. $\varepsilon_{g}$ and $u_{g}$ are two standard errors.

\section{Results}

\subsection{The Effect of the 1977 Reform on Education in Ecuador: First-stage Results}

First, we report the results from our first-stage regressions to examine the effect of the 1977 reform on education in Ecuador. As described in Section 3, the reform was targeted to those students who would not have continued their education in the absence of the increased compulsory schooling age. Our dependent variables are both the secondary school level and the years of schooling. Table 3 reports the results from equation (2), which is our first stage for the fuzzy RDD. We present two estimates, one setting the pivotal cohort at 1964 and the other one at 1965 (Braga and Bratti, 2013). We consider the 27-57 age sample ${ }^{11}$. Table 3 indicates the effect of the reform dummy, $R e f_{g}{ }^{12}$. In Panel A, we consider 1964 as the cut-off point, while in Panel B, the cut-off point is 1965 . We analyze the effect of the reform on the attainment of a secondary level of education, on a secondary or higher level of schooling, and on each year of schooling.

In the last step of the estimation (RDD-2SLSIV), we set the pivotal cohorts to 1964 both for all individuals and for men and women, so that we can avoid the weak-instrument problem. Overall, the reform seems to have produced a significant positive effect on the probability of completing a secondary education, which accounts for $5 \%$ of women and $4 \%$ of men ${ }^{13}$. To look at the effect of the reform on the treated individuals who were born in 1964 or the following years and who were required to stay one or more additional years in school, the effect of the reform is positive and significant, particularly for women (3.45 years for men and 4.27 years for women).

In conclusion, the overall educational level of Ecuadorians increased because of

\footnotetext{
${ }^{11}$ The sample age range has been constructed by considering plus or minus 15 years around the cutoff point, 1964, and this is one of the possible age ranges considered by the literature on educational reforms (Another possibility is plus or minus 10 years; however, we prefer the first sample because it gives the possibility of controlling for one complete school cycle).

${ }^{12} \mathrm{~F}$-tests on the excluded instrument are strong and reported in the Appendix.

${ }^{13}$ The magnitude of the effect is higher if we compare our results with the reforms used by LlerasMuney (2005) for the United States and the reform used by Braga and Bratti (2013) for Italy.
} 
the 1977 educational reform: girls tended to complete two more years of secondary school than boys.

Table 3: First-stage results

\begin{tabular}{lccc|ccc}
\hline & \multicolumn{3}{c}{ Panel A: 1964 cut-off } & \multicolumn{3}{c}{ Panel B: 1965 cut-off } \\
& Total & Men & Women & Total & Men & Women \\
& $(1)$ & $(2)$ & $(3)$ & $(4)$ & $(5)$ & $(6)$ \\
\hline Dep. Var.: Lower Secondary & & & & & & \\
Reform (d) & $0.0449^{* * *}$ & $0.0412^{* * *}$ & $0.0484^{* * *}$ & $0.0373^{* * *}$ & $0.0387^{* *}$ & $0.0359^{* *}$ \\
& $(4.19)$ & $(2.62)$ & $(3.30)$ & $(3.46)$ & $(2.46)$ & $(2.42)$ \\
$\mathrm{R}^{2}$ & 0.0887 & 0.0885 & 0.0924 & 0.0885 & 0.0884 & 0.0921 \\
Obs. & 27,132 & 13,046 & 14,086 & 27,132 & 13,046 & 14,086 \\
\hline Dep. Var.: Years of Schooling & & & & & & \\
Reform (d) & 0.1637 & -0.0109 & $0.2853^{*}$ & $0.2202^{* *}$ & 0.0885 & $0.2843^{*}$ \\
& $(1.50)$ & $(-0.07)$ & $(1.87)$ & $(2.04)$ & $(0.58)$ & $(1.89)$ \\
$\mathrm{R}^{2}$ & 0.2760 & 0.2786 & 0.3068 & 0.2760 & 0.2786 & 0.3068 \\
Obs. & 27,132 & 13,046 & 14,086 & 27,132 & 13,046 & 14,086 \\
\hline \hline
\end{tabular}

Notes: ${ }^{*} \mathrm{p}<0.10,{ }^{* *} \mathrm{p}<0.05,{ }^{* * *} \mathrm{p}<0.01$. Ordinary Least Squares estimates. (d) indicates discrete change of dummy variable from 0 to 1 . Robust standard errors in parenthesis.

\subsection{Baseline Model: Reduced Form and Ordinary Least Squares}

Before showing the RDD results, we report Ordinary Least Squares (OLS) estimates as a benchmark. First, we present our results with and without the controls for emigrants in general, and then we differentiate the sample by gender and focus our attention on female characteristics (Table 4).

In columns 1 and 2, we consider the dependent variable to be a dummy equal to 1 if an individual is an emigrant and 0 otherwise. The results for men are demonstrated in columns 3 and 4 and those for women are indicated in columns 5 and 6 . All coefficients are positive and significant at the $1 \%$ significance level for both of the OLS regressions, which are with and without the control variables ${ }^{14}$. Robust standard errors are in parenthesis. Having a lower secondary educational level increases the migration propensity in line with the positive self-selection literature on migration behavior. Taking into account all controls, a different behavior emerges between men and women. Considering family characteristics, being married has a negative impact on the women's migration behavior. In

\footnotetext{
${ }^{14}$ See the Appendix for the complete results with all control variables.
} 
Table 4: OLS results

\begin{tabular}{lcc|cc|cc}
\hline \hline & \multicolumn{2}{c}{ Total } & \multicolumn{2}{c}{ Men } & \multicolumn{2}{c}{ Women } \\
& $(1)$ & $(2)$ & $(3)$ & $(4)$ & $(5)$ & $(6)$ \\
\hline Lower Secondary $(\mathrm{d})$ & $0.0298^{* * *}$ & $0.0175^{* * *}$ & $0.0302^{* * *}$ & $0.0146^{* * *}$ & $0.0289^{* * *}$ & $0.0171^{* * *}$ \\
& $(9.85)$ & $(5.83)$ & $(6.52)$ & $(3.29)$ & $(7.43)$ & $(4.35)$ \\
Controls & No & Yes & No & Yes & No & Yes \\
$\mathrm{R}^{2}$ & 0.0440 & 0.1239 & 0.0781 & 0.2230 & 0.0181 & 0.0793 \\
\hline Years of School. & $0.0105^{* * *}$ & $0.0064^{* * *}$ & $0.0127^{* * *}$ & $0.0063^{* * *}$ & $0.0078^{* * *}$ & $0.0043^{* * *}$ \\
& $(14.60)$ & $(8.76)$ & $(10.84)$ & $(5.46)$ & $(8.76)$ & $(4.67)$ \\
Controls & No & Yes & No & Yes & No & Yes \\
$\mathrm{R}^{2}$ & 0.0469 & 0.1242 & 0.0803 & 0.2277 & 0.0234 & 0.0796 \\
\hline Obs. & 27,132 & 27,132 & 13,046 & 13,046 & 14,086 & 14,086 \\
\hline \hline
\end{tabular}

Notes: $* \mathrm{p}<0.10,{ }^{* *} \mathrm{p}<0.05,{ }^{* * *} \mathrm{p}<0.01$. Ordinary Least Squares estimates. Dependent variable: binary variable which is equal to 1 if an individual is a migrant and is equal to 0 otherwise. (d) indicates discrete change of dummy variable from 0 to 1 . Robust standard errors in parenthesis.

contrast, being married can be viewed as a push factor for the men to improve their overall family wealth. A large family has a positive and greater effect on the probability that women will migrate rather than men because the Ecuadorian family structure is male-based. We disaggregate the number of children in the household into three groups (children younger than 4 years old, children between 5 and 12 years old, and children between 13 and 15 years old) to analyze different child care costs and the opportunity costs of migration. Our results indicate that an increase in the children's ages decreases the women's migration propensity, so that younger children have a negative effect on the women's probability of emigrating. Another aspect to consider is one's employment status. This has a negative effect on the men's migration propensity when they are already employed; i.e., the migration propensity decreases by almost $6 \%$ with respect to men who are unemployed. This is also consistent with the negative coefficient of our wealth index, which is a proxy variable for the household wealth level.

\subsection{Education and Migration Propensity: RDD im- plementation}

After controlling for the baseline models through our OLS estimations, we examine differences in the propensity to migrate between individuals with different educational levels.

We model the decision to migrate as in equation (1) and estimate the migration 
probability as a function of individual and household characteristics with regional and provincial fixed effects to deal with the country variations. Although we have checked the robustness of our results according to the introduction of a number of control variables, the simple way to estimate the migration-education relationship through an OLS analysis will be biased if our empirical model is affected by endogeneity concerns and therefore, it would not provide a consistent estimate of the impact of education on the emigration propensity by gender. To address the causal relationship, we estimate the system of equations (1) and (2) through the RDD strategy and implement a $2 \mathrm{SLSIV}^{15}$. As noted in the identification strategy paragraph, our IV is the 1977 Ecuadorian educational reform.

Table 5 shows the results when considering gender differentials and area of origin. In columns 1-3, the results are for all individuals; columns 4-6 represent the male subsample, and columns 7-9 represent the female subsample. Robust standard errors are in parenthesis. An exogenous increase in human capital, which is defined as having a secondary level of education, increases the propensity to migrate by $31.30 \%$ and this coefficient is even higher and significant at the $1 \%$ significance level if we only consider individuals from urban areas. The coefficients are not significant for men but they are positive and statistically significant for women. Having a secondary level of education increases the women's migration propensity by almost $22 \%$ and it is almost $39 \%$ for the women from urban areas. Looking at the control variables, it is interesting to notice that the household composition affects the behavior of men and women differently. Having children within the household is negative and significant for women ${ }^{16}$. Having elderly parents at home increases the probability of migration for women but decreases the probability for men. The opposite is also found in the case of married status: the coefficient is positive and significant for men, but negative and significant for women.

\footnotetext{
${ }^{15}$ This is a 'fuzzy' RDD because the compliance to the reform was not perfect since it started. The results from the RDD are divided with respect to gender and location (urban and rural areas).

${ }^{16}$ It decreases the migration propensity by $3 \%$ if a child's age is between 0 and 5 , while it is close to $2 \%$ if a child's age is in the range of 6 to 15 years old. The coefficients are larger in magnitude but they maintain equal statistical significance for women who migrate from urban areas.
} 


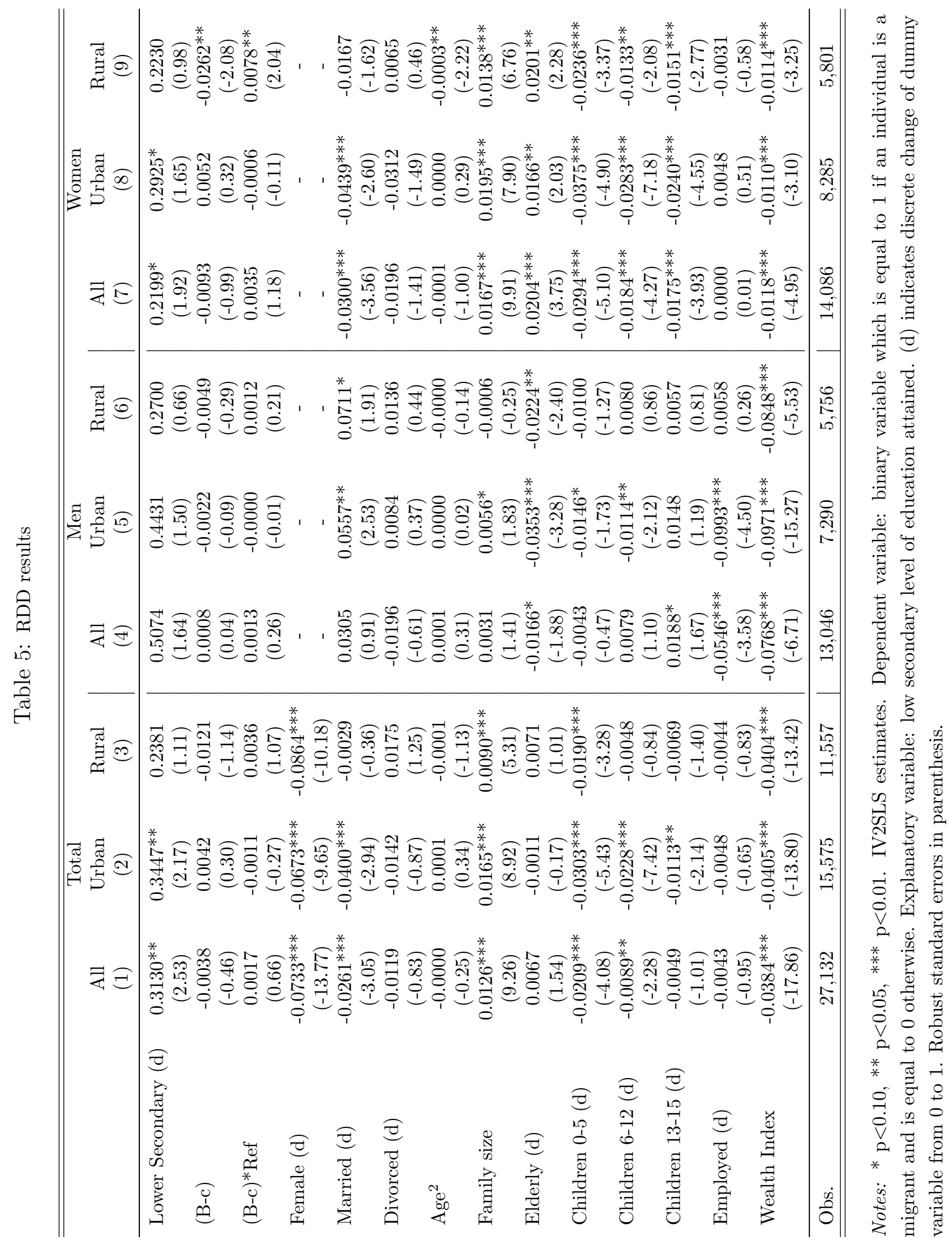


The second part of the analysis is devoted to analyzing the effect of one additional year of schooling on migration behavior. To better examine this factor, we divide the sample by the educational level attained. We separate the individuals with a primary level of education from those with a secondary level of schooling and a university degree. Our results are reported in Table 6. As in Table 5, we divide our sample by gender. In this case, the coefficients are not statistically significant; therefore, an exogenous increase of one year in school does not seem to affect the migration propensity. What really matters in the decision to emigrate is the level of education attained by each individual.

Table 6: RDD results

\begin{tabular}{lccc}
\hline \hline & Primary & Secondary & University \\
\hline Panel A: All & & & \\
Years of Schooling & 0.1029 & 0.0937 & 0.2834 \\
& $(1.39)$ & $(1.06)$ & $(0.60)$ \\
Obs. & 12,491 & 8,270 & 4,590 \\
\hline Panel B: Men & & & \\
Years of Schooling & 0.0566 & 0.2720 & $-11,553$ \\
& $(0.77)$ & $(1.13)$ & $(-0.05)$ \\
Obs. & 6,201 & 3,999 & 2,191 \\
\hline Panel C: Women & & & \\
Years of Schooling & 0.1752 & -0.0366 & 0.8737 \\
& $(0.75)$ & $(-0.30)$ & $(0.44)$ \\
Obs. & 6,290 & 4,273 & 2,399 \\
\hline \hline
\end{tabular}

Notes: ${ }^{*} \mathrm{p}<0.10,{ }^{* *} \mathrm{p}<0.05,{ }^{* * *} \mathrm{p}<0.01$. IV2SLS estimates. Dependent variable: binary variable which is equal to 1 if an individual is a migrant and is equal to 0 otherwise. Years of Schooling as explanatory variable. Robust standard errors in parenthesis.

\section{Discussion of the Results and Conclusions}

This study examines how education affects the migration propensity. Using an original Ecuadorian survey conducted in 2006, we implement a RDD, controlling for potential endogeneity in the educational explanatory variable.

Empirically, we find that increasing the level of education can be treated as a migration push factor for individuals. Splitting the sample between men and women, and differentiating between urban and rural areas, the effect of additional schooling is positive and significant for women, where the coefficient is higher for women from urban areas; whereas it is no longer significant but still 
positive for men.

A possible explanation of these results could be in line with the idea that the propensity to migrate increases with an exogenous variation in the acquisition of human capital, especially for women. This is one possible response to labor market distortions in the country of origin in the case of wage differentials by gender. The descriptive tables in Figure 4 in the Appendix confirm our interpretation of the results. By plotting individual monthly wages by gender and educational level to look at the individual wage variations, we find that in the case of people with no education and a monthly wage less than $\$$ US100, $66.83 \%$ are women. This percentage remains the same at this wage range for all educational levels. Looking at individuals with either no education or a primary or secondary level education, men are still the majority of individuals with a wage between $\$$ US100 and $\$$ US1000. The only difference that really draws our attention is the case of a university-level education. In the first two wage ranges (with a salary less than $\$$ US300 per month), the percentage of women is higher than that for men. This implies that when one considers individuals with the same skills and education, women have lower wages than men. This conclusion seems to support the positive self-selection of women who are likely to migrate due to a negative selection based on wage differentials within Ecuador.

The evidence presented in the study is consistent with both the literature related to a migrant's positive self-selection and the gender wage diversity in the case of labor market distortions ${ }^{17}$. Since the 1980s, Ecuador has made relevant progress in reducing gender disparities and addressing gender-related development issues, in particular educational and labor force participation rates (Correira and Van Bronkhorst, 2000) and the recent reduction in the gender gap, which is primarily due to the higher level of women's human capital such as schooling. The wage structure indicates that even if men and women have the same skills and productive characteristics, men have higher wage returns than women.

\footnotetext{
${ }^{17}$ Between 2003 and 2007 the gender gap in Ecuador has been fluctuating between $7.1 \%$ and $11.2 \%$; the percentages are even higher when considering the urban subgroup (Gallardo and Nopo, 2009).
} 


\section{References}

Acemoglu, D. and Angrist, J. (1991). Does Compulsory School Attendance Affect Schooling and Earnings? The Quarterly Journal of Economics, 106(4):9791014 .

Acemoglu, D. and Angrist, J. (1999). How Large are the Social Return to Education? Evidence from Compulsory Schooling Laws. Technical Report 7444.

Bang, J. and Mitra, A. (2011). Gender bias and the female brain drain. Applied Economics Letters, 18(9):829-833.

Baudassé, T. and Bazillier, R. (2011). Gender Discrimination and Emigration: Push Factor Versus Screening Process Hypothesis. Working papers, HAL.

Behrman, J. R. and Deolalikar, A. B. (1987). Will Developing Country Nutrition Improve with Income? A Case Study for Rural South India. Journal of Political Economy, 95(3):492-507.

Beine, M., Docquier, F., and Rapoport, H. (2001). Brain drain and economic growth: theory and evidence. Journal of Development Economics, 64(1):275289.

Beine, M., Docquier, F., and Rapoport, H. (2010). On the Robustness of Brain Gain Estimates. Annales d'Economie et de Statistique, (97-98):143-165.

Beine, M. and Salomone, S. (2013). Network Effects in International Migration: Education versus Gender. Scandinavian Journal of Economics, 115(2):354-380.

Bertoli, S. (2010). Networks, Sorting and Self-selection of Ecuadorian Migrants. Annales d'Economie et de Statistique, (97-98):261-288.

Bertoli, S., Fernández-Huertas Moraga, J., and Ortega, F. (2013). Crossing the border: Self-selection, earnings and individual migration decisions. Journal of Development Economics, 101(C):75-91.

Bertoli, S. and Marchetta, F. (2014). Migration, Remittances and Poverty in Ecuador. Journal of Development Studies, 50(8):1067-1089.

Bertoli, S., Moraga, J. F.-H., and Ortega, F. (2011). Immigration Policies and the Ecuadorian Exodus. World Bank Economic Review, 25(1):57-76. 
Borjas, G. J. (1987). Self-Selection and the Earnings of Immigrants. American Economic Review, 77(4):531-53.

Borjas, G. J. (1991). Immigration and Self-Selection. In Immigration, Trade, and the Labor Market, NBER Chapters, pages 29-76. National Bureau of Economic Research, Inc.

Braga, M. and Bratti, M. (2013). The effect of schooling on health: Evidence on several health outcomes and behaviors. Health, Econometrics and Data Group (HEDG) Working Papers 13/19, HEDG, c/o Department of Economics, University of York.

Chiquiar, D. and Hanson, G. H. (2005). International Migration, Self-Selection, and the Distribution of Wages: Evidence from Mexico and the United States. Journal of Political Economy, 113(2):239-281.

Chiswick, B. R. (2000). Are Immigrants Favorably Self-Selected? An Economic Analysis. IZA Discussion Papers 131, Institute for the Study of Labor (IZA).

Correira, M. and Van Bronkhorst, B. (2000). Ecuador Gender Review: Issues and Recommendations. World Bank Publication.

Docquier, F., Lowell, B. L., and Marfouk, A. (2008). A gendered assessment of the brain drain. Policy Research Working Paper Series 4613, The World Bank.

Docquier, F., Marfouk, A., Salomone, S., and Sekkat, K. (2012). Are Skilled Women More Migratory than Skilled Men? World Development, 40(2):251265.

Dumont, J. C., Martin, J. P., and Spielvogel, G. (2007). Women on the Move: The Neglected Gender Dimension of the Brain Drain. IZA Discussion Papers, (2920).

Dustmann, C. and Glitz, A. (2011). Migration and Education. Norface Discussion Paper Series 2011011, Norface Research Programme on Migration, Department of Economics, University College London.

Feliciano, C. (2005). Educational Selectivity in U.S. Immigration: How Do Immigrants Compare to Those Left Behind? Demography, 42(1):139-152. 
Feliciano, C. (2008). Gendered Selectivity: U.S. Mexican Immigrants and Mexican Non- Migrants, 1960-2000. Latin American Research Review, 43(1):139160.

Ferrant, G. and Tuccio, M. (2015). South-South Emigration and Discriminatory Social Institutions: a Two-Way Relationship. OECD Development Centre Working Paper.

Fort, M., Schneeweis, N., and Winter-Ebmer, R. (2011). More Schooling, More Children: Compulsory Schooling and Fertility in Europe. IZA Discussion Paper, (6015).

Gallardo, L. and Nopo, H. (2009). Ethnic and Gender Wage Gaps in Ecuador. Research Department Publications, (4625).

Grogger, J. and Hanson, G. H. (2011). Income maximization and the selection and sorting of international migrants. Journal of Development Economics, 95(1):42-57.

Ibarraran, P. and Lubotsky, D. (2007). Immigration and Self-Selection: New Evidence from the 2000 Mexican Census. University of Chicago Press, pages 159-192.

Jokisch, B. and Pribilsky, J. (2002). The Panic to Leave: Economic Crisis and the New Emigration from Ecuador. International Migration, 40(4):76-101.

Kanaiaupuni, S. M. (2000). Reframing the Migration Question: An Analysis of Men, Women, and Gender in Mexico. Social Forces, 78(4):1311-1347.

Larrea, C. (2004). Pobreza, Dolarización y Crisis en el Ecuador. Ediciones AbyaYal.

Lee, S. and Lemieux, T. (2010). Regression Discontinuity Designs in Economics. Journal of Economic Literature, 48(2):281-355.

Lleras-Muney, A. (2005). The relationship between education and adult mortality in the United States. Review of Economic Studies, 72:189-221.

McKenzie, D. and Rapoport, H. (2010). Self-Selection Patterns in Mexico-U.S. Migration: The Role of Migration Networks. The Review of Economics and Statistics, 92(4):811-821. 
Moraga, J. F.-H. (2011). New Evidence on Emigrant Selection. The Review of Economics and Statistics, 93(1):72-96.

Mountford, A. (1997). Can a brain drain be good for growth in the source economy? Journal of Development Economics, 53(2):287-303.

Sjaastad, L. (1962). The Costs and Returns of Human Migration. Journal of Political Economy, 70(5):80-93.

Soruco, X., Piani, G., and Rossi, M. (1951). What Emigration Leaves Behind: The Situation of Emigrants and their Families in Ecuador. Research Department Publications, (3244).

Stark, O., Helmenstein, C., and Prskawetz, A. (1997). A brain gain with a brain drain. Economics Letters, 55(2):227-234.

Thistlethwaite, D. L. and Campbell, D. L. (1960). Regression discontinuity analysis: an alternative to the ex post facto experiment. Journal of Educational Psychology, 51(6):309-317. 


\section{A Appendix}

Figure 3: RDD graphical representation

(a) Yeas of schooling: all

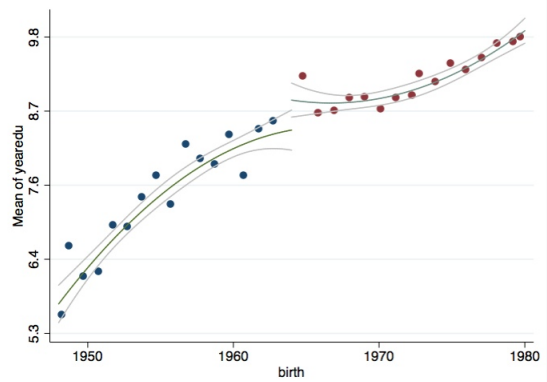

(c) Yeas of schooling: Men

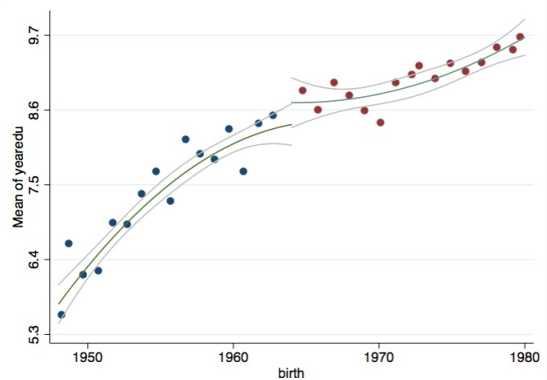

(e) Yeas of schooling: Women

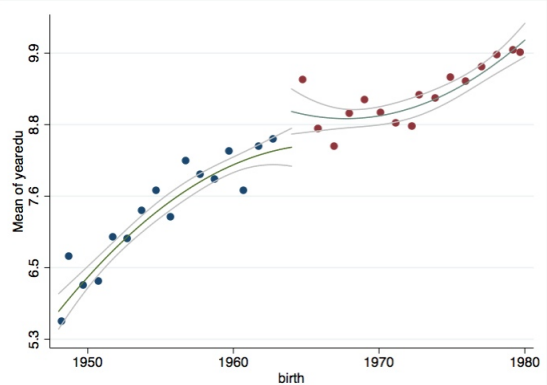

(b) Lower Secondary: all

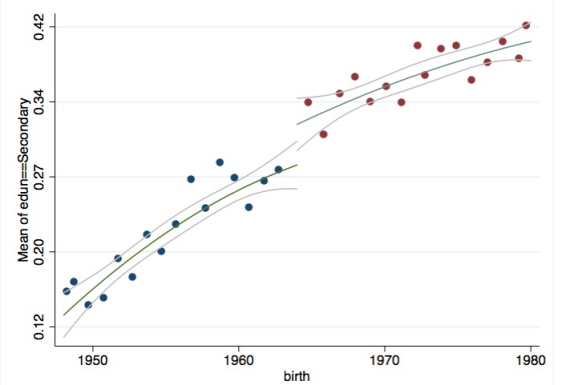

(d) Lower Secondary: Men

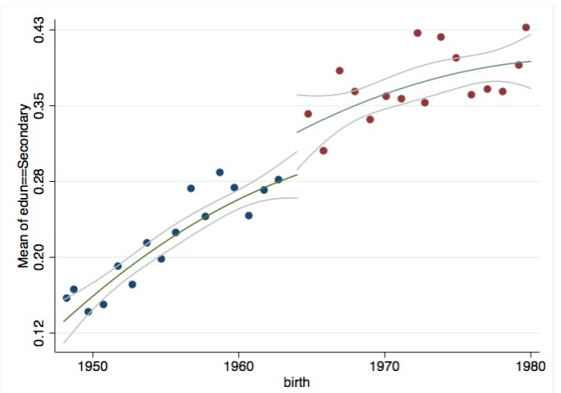

(f) Lower Secondary: Women

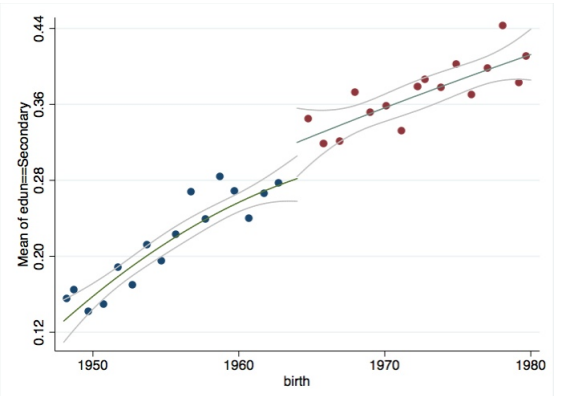

Notes: The sample includes observation from ENEMDU 2006. The left-hand side graphs includes observations born between 1950 and 1963 as non treated group; the right-hand side from 1964 to 1980 as treated group. 1964 is the cut-off year of birth as defined by the compulsory schooling reform - any individual born before this date is allow to drop out after 6 years of school, while anyone born after this year is required to complete 9 years of school. $95 \%$ confidence intervals are plotted with a gray lines around the mean level. Variables of interest: years of schooling that is the is the number of completed years of schooling; low secondary that is a dummy variable equal to 1 if the respondent has completed a lower secondary level of education. 
Table 7: The effect of the reform on treated individuals

\begin{tabular}{lccc}
\hline \hline & All & Men & Women \\
& $(\mathrm{b} / \mathrm{t})$ & $(\mathrm{b} / \mathrm{t})$ & $(\mathrm{b} / \mathrm{t})$ \\
\hline Reform & $3.9011^{* * *}$ & $3.4509^{* * *}$ & $4.2743^{* * *}$ \\
& $(21.78)$ & $(13.29)$ & $(17.40)$ \\
Controls & Yes & Yes & Yes \\
\hline $\mathrm{R}^{2}$ & 0.3635 & 0.3828 & 0.3450 \\
Obs. & 59,613 & 29,940 & 29,673 \\
\hline \hline
\end{tabular}




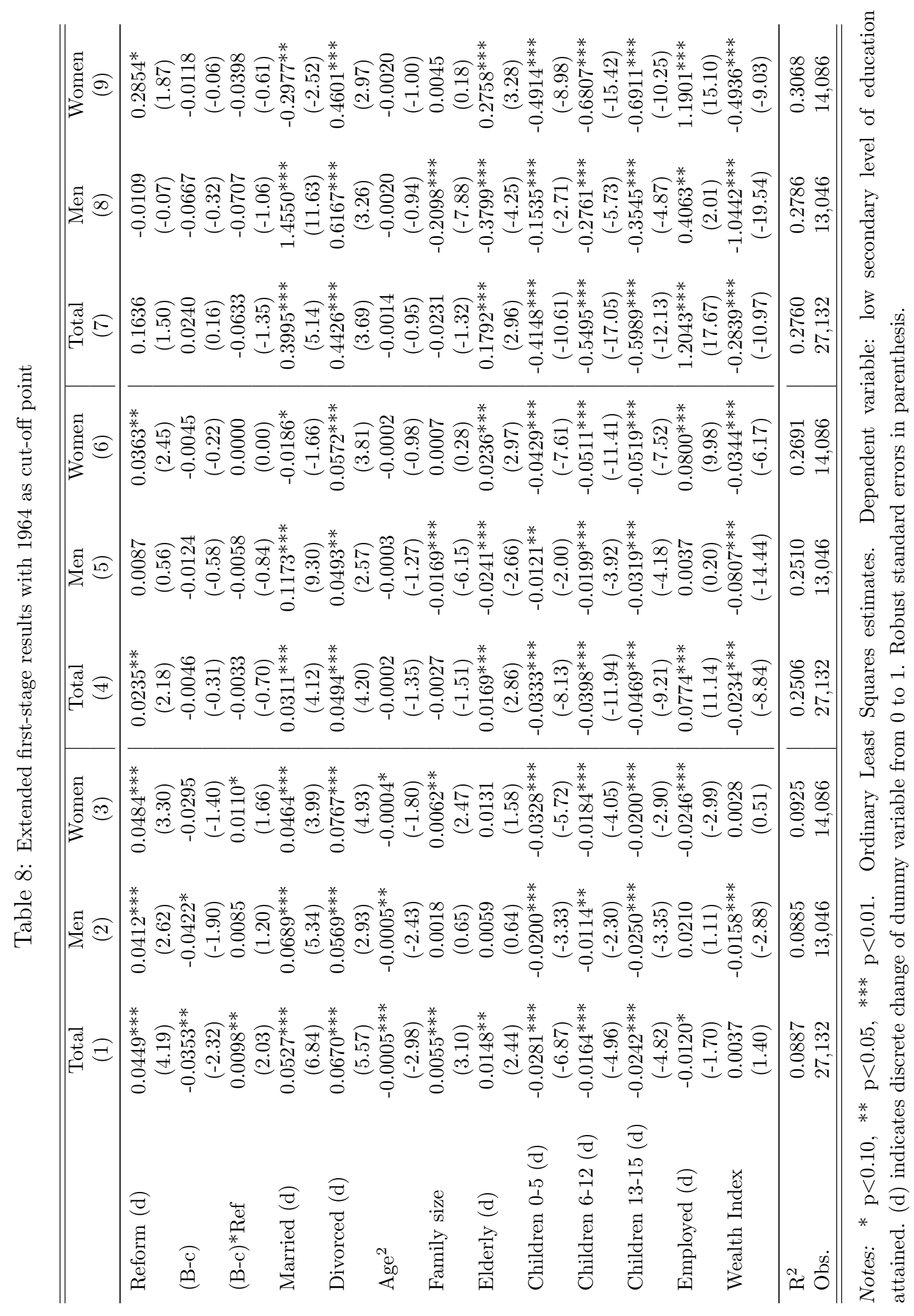




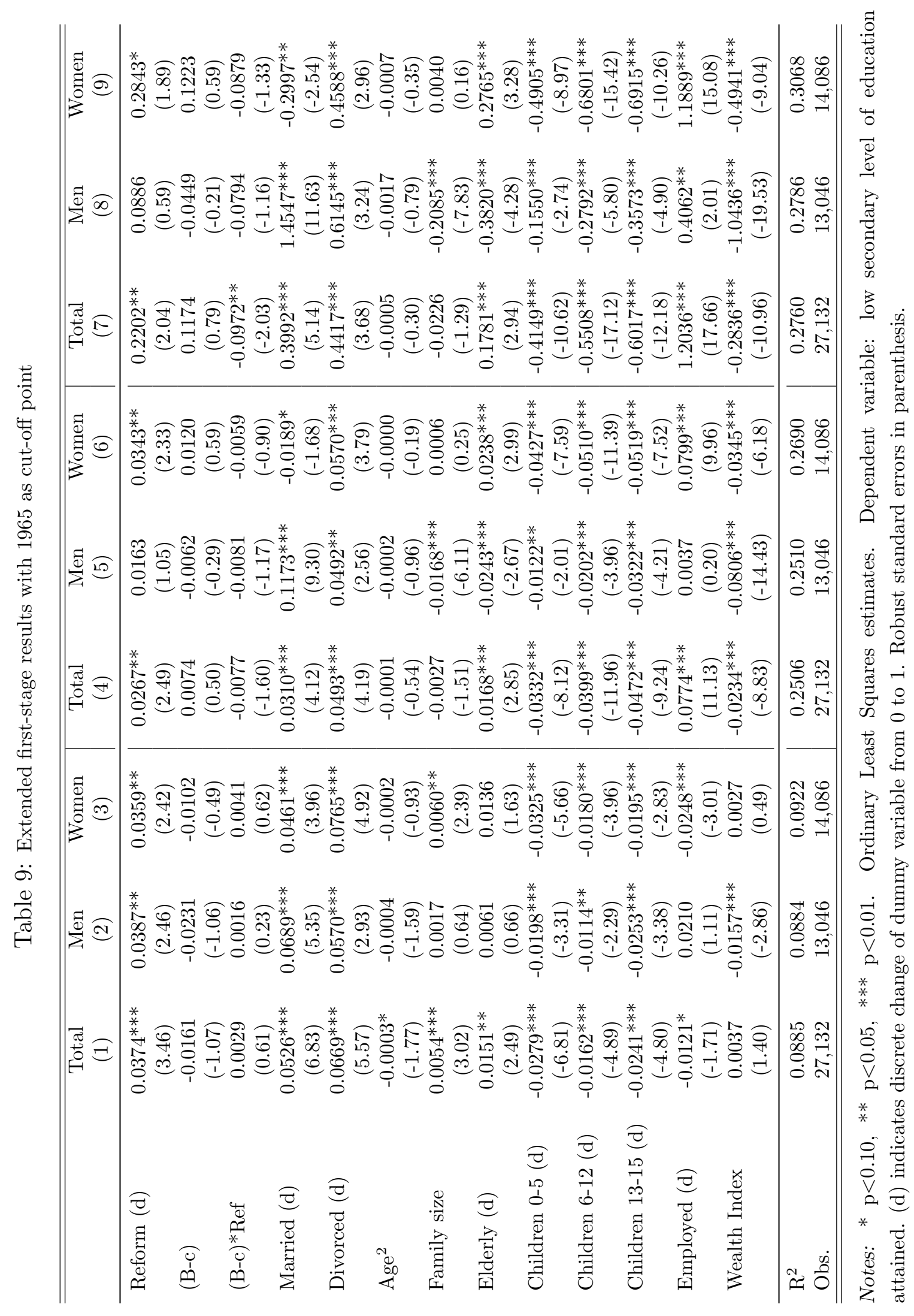


Table 10: First-stage results with F-test

\begin{tabular}{lccc|ccc}
\hline & \multicolumn{3}{c}{ Panel A: 1964 cutoff } & \multicolumn{3}{c}{ Panel B: 1965 cutoff } \\
& Total & Men & Women & Total & Men & Women \\
& $(1)$ & $(2)$ & $(3)$ & $(4)$ & $(5)$ & $(6)$ \\
\hline Dep. Variable: Lower Secondary & & & & & & \\
Reform (d) & $0.0449^{* * *}$ & $0.0412^{* * *}$ & $0.0484^{* * *}$ & $0.0373^{* * *}$ & $0.0387^{* *}$ & $0.0359^{* *}$ \\
& $(4.19)$ & $(2.62)$ & $(3.30)$ & $(3.46)$ & $(2.46)$ & $(2.42)$ \\
$\mathrm{R}^{2}$ & 0.0887 & 0.0885 & 0.0924 & 0.0885 & 0.0884 & 0.0921 \\
Obs. & 27,132 & 13,046 & 14,086 & 27,132 & 13,046 & 14,086 \\
F-Test & 17.52 & 6.88 & 10.90 & 11.98 & 6.06 & 5.83 \\
P-value & 0.0000 & 0.0000 & 0.0000 & 0.0000 & 0.0000 & 0.0000 \\
\hline Dep. Variable: Years of Schooling & & & & & & \\
Reform (d) & 0.1637 & -0.0109 & $0.2853^{*}$ & $0.2202^{* *}$ & 0.0885 & $0.2843^{*}$ \\
& $(1.50)$ & $(-0.07)$ & $(1.87)$ & $(2.04)$ & $(0.58)$ & $(1.89)$ \\
$\mathrm{R}^{2}$ & 0.2760 & 0.2786 & 0.3068 & 0.2760 & 0.2786 & 0.3068 \\
Obs. & 27,132 & 13,046 & 14,086 & 27,132 & 13,046 & 14,086 \\
F-Test & 2.25 & 0.01 & 3.51 & 4.17 & 0.34 & 3.58 \\
P-value & 0.1332 & 0.9431 & 0.0612 & 0.0410 & 0.5586 & 0.0584 \\
\hline \hline
\end{tabular}

Notes: $* \mathrm{p}<0.10, * * \mathrm{p}<0.05,{ }^{* * *} \mathrm{p}<0.01$. Ordinary Least Squares estimates. (d) indicates discrete change of dummy variable from 0 to 1 . Robust standard errors in parenthesis. 
Table 11: OLS results adding controls

\begin{tabular}{|c|c|c|c|c|c|c|}
\hline & $\begin{array}{c}\text { Total } \\
(1)\end{array}$ & $\begin{array}{l}\text { Men } \\
(2)\end{array}$ & $\begin{array}{l}\text { Women } \\
(3)\end{array}$ & $\begin{array}{c}\text { Total } \\
(4)\end{array}$ & $\begin{array}{l}\text { Men } \\
(5)\end{array}$ & $\begin{array}{c}\text { Women } \\
(6)\end{array}$ \\
\hline Low Secondary (d) & $\begin{array}{c}0.0175^{* * *} \\
(5.82)\end{array}$ & $\begin{array}{c}0.0146^{* * *} \\
(3.28)\end{array}$ & $\begin{array}{c}0.0171^{* * *} \\
(4.35)\end{array}$ & & & \\
\hline Years of Schooling & & & & $\begin{array}{c}0.0064^{* * *} \\
(8.74)\end{array}$ & $\begin{array}{c}0.0063^{* * *} \\
(5.43)\end{array}$ & $\begin{array}{c}0.0042^{* * *} \\
(4.65)\end{array}$ \\
\hline Y. Schooling ${ }^{2}$ & & & & $\begin{array}{c}-0.0003^{* * *} \\
(-7.51)\end{array}$ & $\begin{array}{c}-0.0005^{* * *} \\
(-7.70)\end{array}$ & $\begin{array}{c}-0.0001^{* * *} \\
(-2.63)\end{array}$ \\
\hline$(\mathrm{B}-\mathrm{c})$ & $\begin{array}{c}-0.0124^{*} \\
(-1.88)\end{array}$ & $\begin{array}{c}-0.0181^{*} \\
(-1.81)\end{array}$ & $\begin{array}{c}-0.0138^{*} \\
(-1.67)\end{array}$ & $\begin{array}{c}-0.0126^{*} \\
(-1.90)\end{array}$ & $\begin{array}{c}-0.0183^{*} \\
(-1.83)\end{array}$ & $\begin{array}{c}-0.0141^{*} \\
(-1.70)\end{array}$ \\
\hline$(\mathrm{B}-\mathrm{c}) * \operatorname{Ref}$ & $\begin{array}{c}0.0036^{*} \\
(1.73)\end{array}$ & $\begin{array}{l}0.0036 \\
(1.14)\end{array}$ & $\begin{array}{c}0.0052^{* *} \\
(2.02)\end{array}$ & $\begin{array}{c}0.0036^{*} \\
(1.77)\end{array}$ & $\begin{array}{l}0.0034 \\
(1.08)\end{array}$ & $\begin{array}{c}0.0053^{* *} \\
(2.09)\end{array}$ \\
\hline Married (d) & $\begin{array}{c}-0.0092^{* *} \\
(-2.12)\end{array}$ & $\begin{array}{c}0.0855^{* * *} \\
(9.91)\end{array}$ & $\begin{array}{c}-0.0212^{* * *} \\
(-3.27)\end{array}$ & $\begin{array}{c}-0.0105^{* *} \\
(-2.42)\end{array}$ & $\begin{array}{c}0.0878^{* * *} \\
(10.06)\end{array}$ & $\begin{array}{c}-0.0209^{* * *} \\
(-3.21)\end{array}$ \\
\hline Divorced (d) & $\begin{array}{c}0.0184^{* * *} \\
(3.25)\end{array}$ & $\begin{array}{c}0.0303^{* * *} \\
(3.08)\end{array}$ & $\begin{array}{c}0.0011 \\
(0.16)\end{array}$ & $\begin{array}{c}0.0171^{* * *} \\
(3.01)\end{array}$ & $\begin{array}{c}0.0297^{* * *} \\
(3.01)\end{array}$ & $\begin{array}{c}0.0006 \\
(0.09)\end{array}$ \\
\hline $\mathrm{Age}^{2}$ & $\begin{array}{c}-0.0002^{* *} \\
(-2.25)\end{array}$ & $\begin{array}{c}-0.0002^{* *} \\
(-1.99)\end{array}$ & $\begin{array}{c}-0.0002^{* *} \\
(-2.00)\end{array}$ & $\begin{array}{c}-0.0002^{* *} \\
(-2.25)\end{array}$ & $\begin{array}{c}-0.0002^{* *} \\
(-2.02)\end{array}$ & $\begin{array}{c}-0.0002^{* *} \\
(-2.01)\end{array}$ \\
\hline Family size & $\begin{array}{c}0.0144^{* * *} \\
(12.82)\end{array}$ & $\begin{array}{l}0.0027 \\
(1.52)\end{array}$ & $\begin{array}{c}0.0184^{* * *} \\
(12.47)\end{array}$ & $\begin{array}{c}0.0142^{* * *} \\
(12.65)\end{array}$ & $\begin{array}{c}0.0018 \\
(0.99)\end{array}$ & $\begin{array}{c}0.0184^{* * *} \\
(12.42)\end{array}$ \\
\hline Elderly (d) & $\begin{array}{c}0.0065 \\
(1.60)\end{array}$ & $\begin{array}{c}-0.0267^{* * *} \\
(-4.26)\end{array}$ & $\begin{array}{c}0.0209^{* * *} \\
(3.97)\end{array}$ & $\begin{array}{c}0.0066 \\
(1.63)\end{array}$ & $\begin{array}{c}-0.0281^{* * *} \\
(-4.47)\end{array}$ & $\begin{array}{c}0.0208^{* * *} \\
(3.95)\end{array}$ \\
\hline Children 0-5 (d) & $\begin{array}{c}-0.0320^{* * *} \\
(-15.00)\end{array}$ & $\begin{array}{c}-0.0183^{* * *} \\
(-5.99)\end{array}$ & $\begin{array}{c}-0.0385^{* * *} \\
(-13.10)\end{array}$ & $\begin{array}{c}-0.0315^{* * *} \\
(-14.75)\end{array}$ & $\begin{array}{c}-0.0178^{* * *} \\
(-5.83)\end{array}$ & $\begin{array}{c}-0.0379^{* * *} \\
(-12.91)\end{array}$ \\
\hline Children 6-12 (d) & $\begin{array}{c}-0.0174^{* * *} \\
(-9.94)\end{array}$ & $\begin{array}{l}-0.0035 \\
(-1.28)\end{array}$ & $\begin{array}{c}-0.0250^{* * *} \\
(-11.19)\end{array}$ & $\begin{array}{c}-0.0169^{* * *} \\
(-9.69)\end{array}$ & $\begin{array}{c}-0.0038 \\
(-1.41)\end{array}$ & $\begin{array}{c}-0.0240^{* * *} \\
(-10.77)\end{array}$ \\
\hline Children 13-15 (d) & $\begin{array}{c}-0.0150^{* * *} \\
(-6.31)\end{array}$ & $\begin{array}{c}0.0018 \\
(0.49)\end{array}$ & $\begin{array}{c}-0.0238^{* * *} \\
(-8.13)\end{array}$ & $\begin{array}{c}-0.0146^{* * *} \\
(-6.17)\end{array}$ & $\begin{array}{c}0.0012 \\
(0.33)\end{array}$ & $\begin{array}{c}-0.0228^{* * *} \\
(-7.78)\end{array}$ \\
\hline Employed (d) & $\begin{array}{c}-0.0090^{* *} \\
(-2.56)\end{array}$ & $\begin{array}{c}-0.0604^{* * *} \\
(-4.59)\end{array}$ & $\begin{array}{c}-0.0042 \\
(-1.23)\end{array}$ & $\begin{array}{c}-0.0091^{* *} \\
(-2.51)\end{array}$ & $\begin{array}{c}-0.0622^{* * *} \\
(-4.68)\end{array}$ & $\begin{array}{c}-0.0059^{*} \\
(-1.68)\end{array}$ \\
\hline Wealth Index & $\begin{array}{c}-0.0396^{* * *} \\
(-21.25)\end{array}$ & $\begin{array}{c}-0.0956^{* * *} \\
(-23.46)\end{array}$ & $\begin{array}{c}-0.0110^{* * *} \\
(-5.39)\end{array}$ & $\begin{array}{c}-0.0397^{* * *} \\
(-20.99)\end{array}$ & $\begin{array}{c}-0.0990^{* * *} \\
(-23.52)\end{array}$ & $\begin{array}{c}-0.0104^{* * *} \\
(-5.01)\end{array}$ \\
\hline $\mathrm{R}^{2}$ & 0.1240 & 0.2233 & 0.0794 & 0.1244 & 0.2280 & 0.0797 \\
\hline Obs. & 27,132 & 13,046 & 14,086 & 27,132 & 13,046 & 14,086 \\
\hline
\end{tabular}

Notes: ${ }^{*} \mathrm{p}<0.10,{ }^{* *} \mathrm{p}<0.05,{ }^{* * *} \mathrm{p}<0.01$. Ordinary Least Squares estimates. Dependent variable: binary variable which is equal to 1 if an individual is a migrant and is equal to 0 otherwise. (d) indicates discrete change of dummy variable from 0 to 1 . Robust standard errors in parenthesis. 


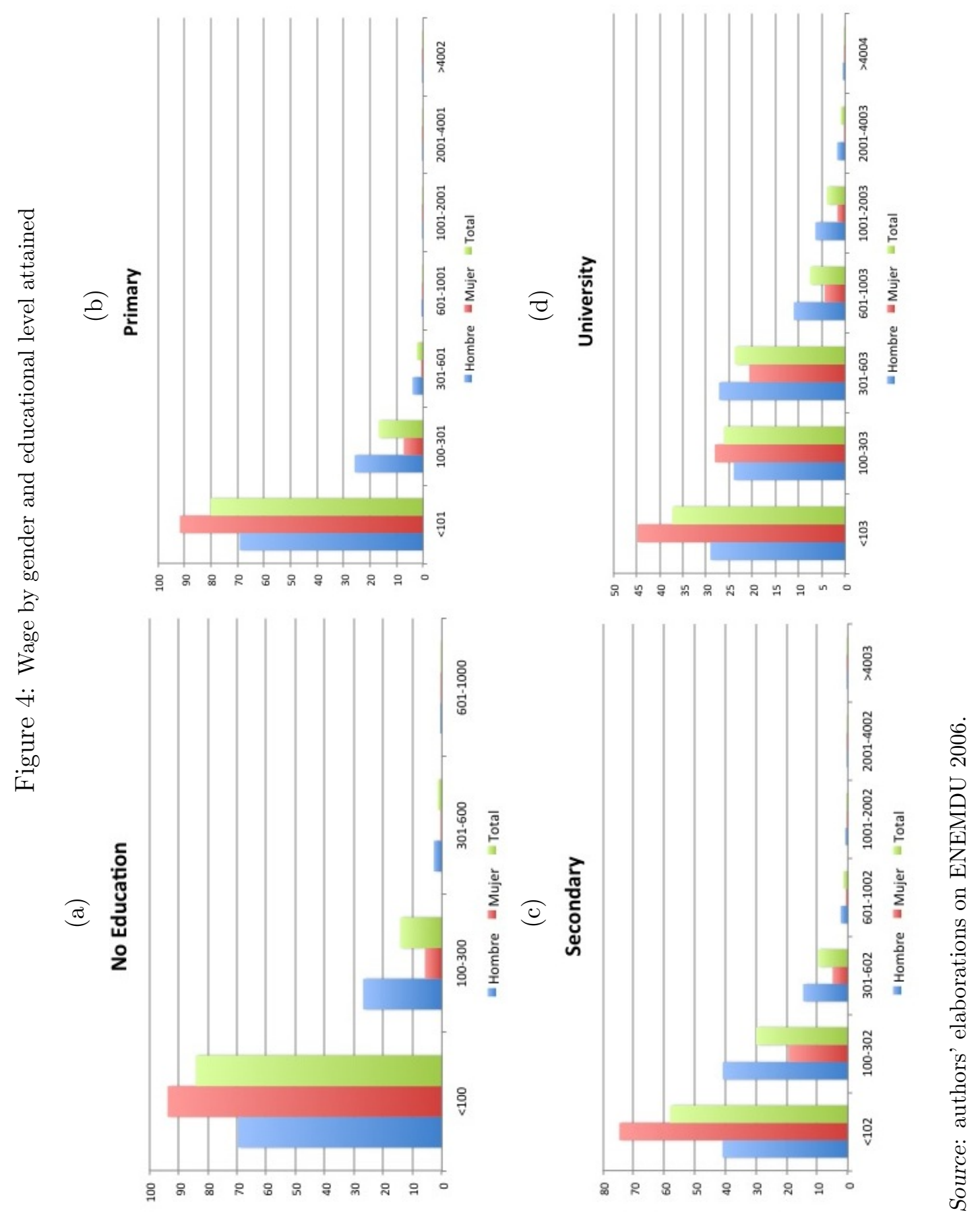

